\title{
Effect of Catchment Area Activities on the Physico-Chemical Characteristics of Water of Upper Lake, Bhopal with Special Reference to Nitrate and Phosphate Concentration
}

\author{
RANJANATALWAR ${ }^{\star}$, SHWETA AGRAWAL ${ }^{1}$, AVINASH BAJPAI ${ }^{2}$ and SUMAN MALIK ${ }^{3}$ \\ *Sadhu Vaswani College, Bairagarh, Bhopal, India. \\ 'Department of Life Sciences, Extol Institute of Management, Bhopal, India. \\ ${ }^{2}$ Makhanlal University, Bhopal, India. \\ ${ }^{3} \mathrm{HOD}$, Sadhu Vaswani College, Bairagarh, Bhopal, India. \\ http://dx.doi.org/10.12944/CWE.9.1.26
}

(Received: January 15, 2014; Accepted: February 18, 2014)

\begin{abstract}
With the tremendous influx of people and consequent urban development, increased anthropogenic activities in the catchment, inflow of untreated sewage, nutrients and pesticides from urban and rural areas, the water quality of Upper Lake, Bhopal has deteriorated significantly. An attempt has been made to study various physico-chemical parameters, specifically nitrates and phosphates of five different sampling sites of Upper Lake and to study the effect of catchment area activities on these sites.
\end{abstract}

Key words: Urban development, Anthropogenic activities, Deteriorated, Catchment areas, Nitrate and Phosphates.

\section{INTRODUCTION}

The construction of storage reservoirs is an age old Practice in India. Upper Lake of Bhopal, arguably the oldest among the largest manmade lakes in central part of India, falls under this category. The study area selected was Upper Lake of Bhopal, Madhya Pradesh. It is the life line of Bhopal created by Raja Bhoj in eleventh century. The Upper Lake is located between latitude $23^{\circ} 12^{\prime}-23^{\circ} 16^{\prime} \mathrm{N}$ and longitude $77^{\circ} 18^{\prime}-77^{\circ} 23^{\prime} \mathrm{E}$. It is a shallow tropical lake. It has a watershed area of $361 \mathrm{~km}^{2}$ and a maximum submergence area of about $37 \mathrm{~km}^{2}$. The attainment of maximum water level (508.04 meters above sea level) of the lake depends on the magnitude of monsoon rainfall (average being around $1150 \mathrm{~mm}$ ) in the watershed area. The water level in the lake is maintained by discharging excess water through a spillway provided on the southern bank of the lake. The Lake has an urban, semiurban and rural catchment area and its water quality is largely affected by various anthropogenic activities around the lake. Amongst the various chemical constituents present in the lake, nitrate and phosphate are two important constituents that immensely help in the growth of the plants. If present in lake and ponds, they excessively promote the growth of aquatic weeds and hence pollute the aquatic resources. International studies on nitrates and phosphates in surface waters of various water bodies have expressed their concern and drawn the attention of scientists around the globe. Water intended for human consumption should be "safe and wholesome" ie free from pathogenic activities and harmful chemicals, pleasant to taste and useable for domestic purpose (Parashar et. al., 2006)

\section{MATERIAL AND METHODS}

The concentration of nitrate and phosphate in water samples is chiefly affected through point and non-point pollution sources such as washing, bathing, agricultural activities in fringe 
areas, joining of domestic raw sewage, cultivation of trapa and huge growth of aquatic macrophytes. The present study was conducted for analysis and interpretation of quality of water samples collected from five different stations of the Upper Lake, located at different catchment areas. The study was carried for two consecutive years ie 2011 and 2012 and the samples were collected in the pre - monsoon and post - monsoon periods. Amongst the various physical and chemical parameters studied and analyzed, the concentration of nitrate and phosphate were studied majorly. Phosphate and nitrate concentration was determined spectrophotometrically as per standard methods prescribed by Adoni, APHA, AWWA and WEF (1998).

The sampling sites selected are as mentioned below :

\section{S1-Bairagarh}

This station of Upper Lake situated near Bairagarh has substantial inflow of domestic sewage. The inflow of nutrient has resulted in significant variation in the water quality parameters. Besides, agricultural activities are also the major source of pollution at this site.

\section{S2-Behta}

This sampling station is situated near the urban settlements of Bairagarh. This station also receives domestic sewage from the adjoining residential areas.

\section{S3-Lake View}

This station of the Upper Lake is less affected due to anthropogenic pressures. This site is chiefly used for recreational purposes.

\section{S4-Gora Bisenkhedi}

This area receives maximum inflow of rainwater during monsoon which brings significant quantity of silt into the lake. Also at this site the lake receives agrochemicals, fertilizers through surface runoff from agricultural lands.

\section{S5-Kaliasote}

This part of the Upper Lake has a Dam which is mainly used for irrigation and recreational purposes.

\section{RESULTS AND DISCUSSIONS}

The water samples analyzed for nitrate and phosphate concentration of Upper Lake, Bhopal showed variations as per the station and period during which the sampling was carried out.

\section{Nitrate}

Nitrate indicates the pollution in ground water due to sewage percolation beneath the surface. Nitrate is also one of the major constituent of the various fertilizers and pesticides, hence through rains it percolates into the lake water. The samples analyzed in the pre-monsoon and postmonsoon season showed that the content of nitrate ranged between 1.27 and $2.76 \mathrm{mg} / \mathrm{ltr}$ in the year 2011 while it ranged between 1.27 and $2.93 \mathrm{mg} / \mathrm{tr}$ in the year 2012. The minimum concentration of $1.27 \mathrm{mg} / \mathrm{tr}$ was observed at sampling station S3. Sadhana Tamot (2006) also observed that the concentration of nitrate in samples of water of Upper Lake, Bhopal was within the acceptable limits although it tends to increase considerably in one year's time. The deterioration in the quality of lake water has contributed to the decline in the biological

Table 1: Variations in Nitrate at different sampling stations of Upper Lake in the year 2011-12

\begin{tabular}{|c|c|c|c|c|c|}
\hline \multirow[b]{2}{*}{$\begin{array}{l}\text { S. } \\
\text { No. }\end{array}$} & \multirow[b]{2}{*}{$\begin{array}{l}\text { Sampling } \\
\text { Station }\end{array}$} & \multicolumn{2}{|c|}{2011} & \multicolumn{2}{|c|}{2012} \\
\hline & & $\begin{array}{c}\text { Pre- } \\
\text { Monsoon }\end{array}$ & $\begin{array}{c}\text { Post- } \\
\text { Monsoon }\end{array}$ & $\begin{array}{c}\text { Pre- } \\
\text { Monsoon }\end{array}$ & $\begin{array}{c}\text { Post- } \\
\text { Monsoon }\end{array}$ \\
\hline 1 & $\mathrm{~S} 1$ & 1.96 & 2.21 & 2.01 & 2.24 \\
\hline 2 & S2 & 2.27 & 2.76 & 2.36 & 2.93 \\
\hline 3 & S3 & 1.27 & 1.31 & 1.44 & 1.48 \\
\hline 4 & S4 & 1.84 & 2.65 & 1.27 & 1.72 \\
\hline 5 & S5 & 1.73 & 2.69 & 1.83 & 2.34 \\
\hline
\end{tabular}


diversity of the flora, fauna and productivity of the wetland systems (Ramachandra, 2001).

\section{Phosphate}

The study carried out in the year 2011 and 2012 in the pre-monsoon and post-monsoon season showed that the concentration of phosphate ranged between 1.22 and $2.43 \mathrm{mg} / \mathrm{tr}$ in the year 2011 while it ranged between 1.95 and $3.12 \mathrm{mg} / \mathrm{tr}$ in the year 2012. There are various sources of phosphate to the lake water, such as runoff from surface catchments, interaction between the water and sediment from dead plant and animal remains at the bottom of the lake. High concentration of phosphorus compounds may produce a secondary problem in water bodies where algal growth is normally limited by the presence of phosphorus. Sonal Trivedi et. al. (2012) observed phosphate concentration of Shahpura Lake, Bhopal and found phosphate concentration to be alarming and very high as compared to the standard guidelines, which

Table 2: Variations in Phosphate at different sampling stations of Upper Lake in the year 2011-12

\begin{tabular}{lcccccc}
\hline & & \multicolumn{2}{c}{2011} & & \multicolumn{2}{c}{2012} \\
$\begin{array}{l}\text { S. } \\
\text { No. }\end{array}$ & $\begin{array}{c}\text { Sampling } \\
\text { Station }\end{array}$ & $\begin{array}{c}\text { Pre- } \\
\text { Monsoon }\end{array}$ & $\begin{array}{c}\text { Post- } \\
\text { Monsoon }\end{array}$ & & $\begin{array}{c}\text { Pre- } \\
\text { Monsoon }\end{array}$ & $\begin{array}{c}\text { Post- } \\
\text { Monsoon }\end{array}$ \\
\hline 1 & S1 & 1.22 & 1.69 & 1.95 & 2.28 \\
2 & S2 & 1.63 & 2.43 & 2.64 & 3.12 \\
3 & S3 & 1.69 & 1.94 & 2.13 & 2.23 \\
4 & S4 & 1.68 & 2.23 & 2.18 & 2.34 \\
5 & S5 & 1.72 & 2.15 & 2.06 & 2.31 \\
\hline
\end{tabular}

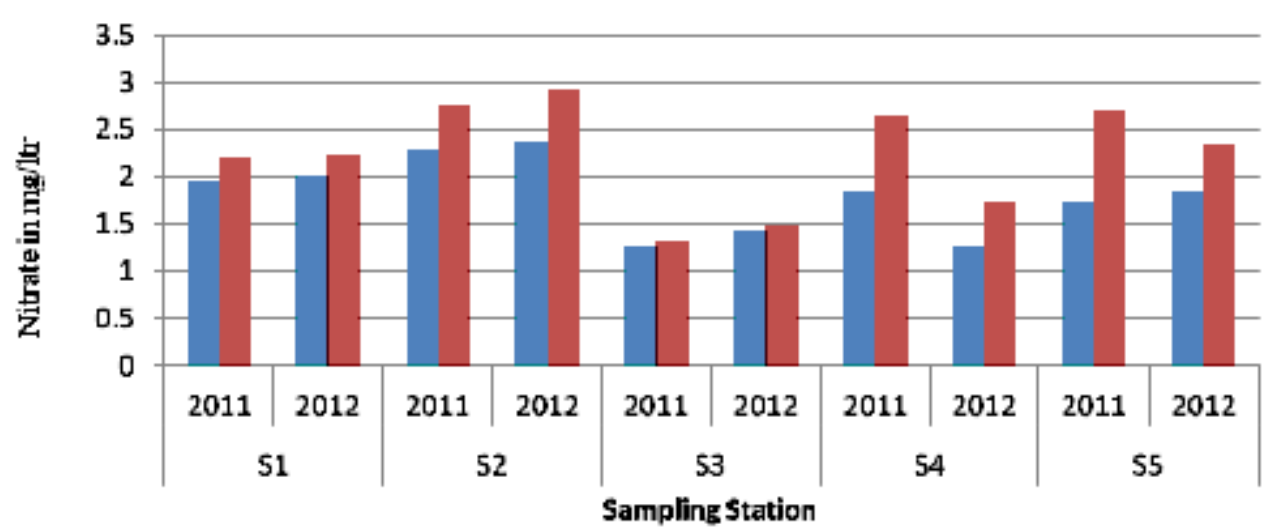

Fig 1: Variation Of Nitrate In The Year 2011 - 12

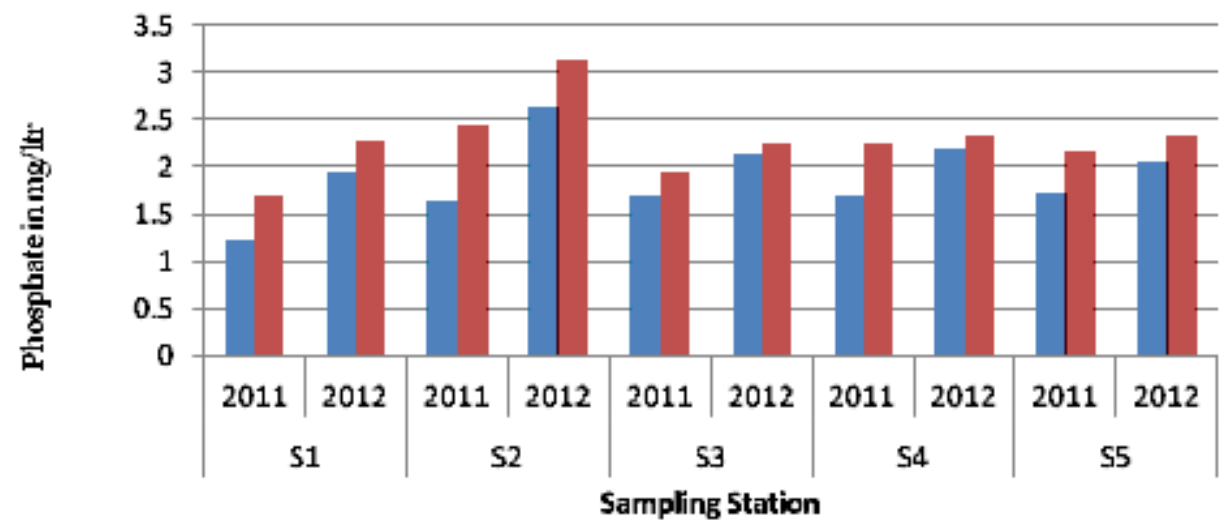

Premonsoon

- Postmonsoon

Fig 2: Variation Of Phosphate In The Year 2011 - 12 
reveals that nutrient load in the lake is very high. Maximum value of phosphate was found during the monsoon season. Sujitha et. al. (2006) observed that the total phosphate value at Pallichal area of Karamana river of Trivandrum showed the deposition of nutrients during monsoon season.

\section{CONCLUSION}

Agriculture is the major source of several non-point source pollutants, including nutrients, sediments, pesticides and salts. Besides, untreated sewage and city garbage coming into the lakes is responsible for the deterioration in its quality. From the study it was observed that the concentration of nitrate and phosphate increases in water after monsoons because of runoff waters from the nearby fertilized land. Also we have observed lower values of both the contents at the sampling point S-3 [Lake View] which is an area of recreational use and free from agricultural activities and anthropogenic pressures. As a result we have not observed any specific change in concentration from pre to post monsoon season. The concentration of nitrate and phosphate have also shown an increased trend from 2011 to 2012 which might be due to an increases use of various chemical fertilizers and pesticides.

\section{REFERENCES}

1. Parashar C., Dixit S. and Shrivastava R. Seasonal Variations in Physico - chemical characteristics in Upper Lake of Bhopal. Asian J. Exp. Sci., 20(2), 297-32 (2006).

2. Adoni A.D. Workbook of Limnology, Pratibha Publication, Sagar, M.P., India (1985).

3. APHA, AWWA, WEF, Standard methods for the examination of water and waste water (20 $0^{\text {th }}$ edn.) Washington, DC: American Public Health Association (1998)

4. De A. K. Environmental Chemistry $4^{\text {th }}$ Edition, New Age International Publishers, New Delhi, 245-252 (2002).

5. Ramachandra T.V. Restoration and management strategies of wetlands in developing countries. Electronic Green Journal, 15: (2001) Retrieved from http:// egj.lib.uidaho.edu/egj15/ramacha1.html.

6. Tamot S. and Sharma P. Physico-chemical status of Upper Lake (Bhopal, India) water quality with special reference to Phosphate and Nitrate concentration and their impact on Lake Ecosystem. Asian J. Exp. Sci., 20(1), 151-158 (2006).

7. Jinwal A. and Dixit S. Pre- and Post-monsoon variation in physic-chemical characteristics in ground water qaulaity of Bhopal "The City of Lakes" India. Asian J. Exp. Sci., 22(3), 311 316 (2008).

8. Sonal Trivedi and H.C. Kataria Physicochemical studies of water quality of Shahpura Lake, Bhopal (M.P.) with special reference to pollution effects on ground water of its fringe areas. Curr World Environ ; 7(1): 139-144 (2012).

9. Sujitha P.C., Mitra Dev D., Sowmya P.K. and Mini Priya R. Physico -chemical parameters of Karamana river water in Trivandrum, India. International Journal of Environmental Sciences, 2(3), Research Article, ISSN 09764402 (2012).

10. Choudhary R., Rawtani P. and Vishwakarma M. Comparative study of drinking water quality parameters of three manmade reservoirs i.e. Kolar, Kaliasote and Kerwa Dam. Curr World Environ, 6(1); 145-149 (2011).

11. Bajpai A., Pani S., Jain R.K. and Mishra S.M. Heavy metals contamination through idol immersion in a tropical lake. Eco. Env and Con. 8(2) 171-173 (2002). 